\title{
Therapeutic Efficacy of Lactonic Sophorolipids: Nanoceria-Assisted Combination Therapy of NSCLC using HDAC and Hsp90 Inhibitors
}

\author{
Shuguftha Naz ${ }^{1}$, Tuhina Banerjee ${ }^{1}$, Filbert Totsingan², Kalee Woody ${ }^{1}$, Richard A. Gross², Santimukul Santra ${ }^{\circledR}$ \\ 1. Department of Chemistry, Pittsburg State University, Pittsburg, Kansas 66762, United States. \\ 2. Department of Chemistry and Chemical Biology, Rensselaer Polytechnic Institute, Troy, New York 12180, United States. \\ $\triangle$ Corresponding author: Santimukul Santra, Ph.D., Associate Professor. Department of Chemistry, Pittsburg State University, Pittsburg, Kansas 66762, United \\ States. Phone: 620-235-4861; Fax: 620-235-4003; E-mail: ssantra@pittstate.edu.
}

(c) The author(s). This is an open access article distributed under the terms of the Creative Commons Attribution License (https://creativecommons.org/licenses/by/4.0/). See http://ivyspring.com/terms for full terms and conditions.

Received: 2020.12.29; Accepted: 2021.03.20; Published: 2021.04.16

\begin{abstract}
Purpose: Non-Small-Cell Lung Cancer (NSCLC) has gained resistance to common chemo- and radiotherapy due to the oncogenic K-RAS mutations. In this work, lactonic sophorolipids (LSL), a constituent of natural sophorolipids known to inhibit histone deacetylase (HDAC) activity, is used to evaluate its potential anticancer property for the treatment of NSCLC. In addition, ganetespib (GT), a Hsp90 inhibitor, is used for its known antitumor activity in several K-RAS mutant NSCLC cells. We propose, a functional anti-oxidant nanomedicine composed of nanoceria (NC) encapsulated with two-drug cocktail LSL and GT for the assessment of therapeutic efficacy of LSL and targeted combination therapy of NSCLC. NC is an excellent redox platform specifically used to supplement the therapeutic potency of these drugs to target both HDAC inhibition and Hsp90 signaling pathways in NSCLC.

Methods: Polyacrylic acid-coated nanoceria (PNC) was formulated and folic acid was conjugated on the surface of PNC using "click" chemistry to target NSCLC and to minimize adverse side effects. Solvent diffusion method was used for the encapsulation of individual drugs and co-encapsulation of drug-cocktail along with an optical dye Dil for diagnosis. We hypothesized that the therapeutic efficacy of LSL will be synergistically accelerated by the inhibition of $\mathrm{Hsp} 90$ mechanism of GT and redox activity of NC.

Results: For the targeted therapy of NSCLC, A549 cells were used and Chinese hamster ovary (CHO) cells were used as healthy control cells. Results showed more than $40 \%$ cells were dead within $24 \mathrm{~h}$ when treated with LSL nanodrug. When combined with GT, enhanced ROS signals were detected and more than $80 \%$ reduction in cell viability was recorded within $24 \mathrm{~h}$ of incubation. Treatments with NC without any drug showed minimal toxicity. Migration assays indicate that the highly metastatic nature of NSCLC is successfully restricted by this combination approach. To validate the effectiveness of this combination therapy various cell-based assays including detection of apoptosis, necrosis and HDAC inhibition of LSL were performed.

Conclusion: Functional nanoceria with drug-cocktail LSL and GT is successfully developed for the targeted treatment of undruggable NSCLC. The fluorescence modality helps monitoring the drugs delivery. Results demonstrate the potential therapeutic efficacy of LSL, which is synergistically accelerated by the Hsp90 inhibition mechanism of GT and redox activity of NC.
\end{abstract}

Key words: lactonic sophorolipid, HDAC inhibition, ganetespib, antioxidant nanoceria, cancer therapy

\section{Introduction}

Histone acetylation and deacetylation plays a crucial role in the regulation of gene expression. These processes are balanced by histone acetylases (HAT) and histone deacetylases (HDAC) [1-3]. Altered expression and mutation of genes associated with HDAC are directly linked to cell proliferation and 
tumor development [4]. Studies have shown that HDAC inhibitors are known to alter gene expression, induce cancer cell apoptosis and death. Thus, the development of HDAC inhibitors, their therapeutic role and mechanism of action has received tremendous attention in the field of cancer treatment [5]. Lactonic sophorolipid (LSL) is a glycolipid molecule synthesized from specific yeast species. Many reports are available on the immunomodulatory and anti-inflammatory properties of LSL [6-11]. Furthermore, studies have reported the anticancer activity of LSL on different cell lines including pancreatic, esophageal and lung cancer. It is indicated that one of the mechanisms for anti-tumor activity of LSL is the HDAC inhibition, where histone deacetylases are inhibited interfering with gene expression [12-16].

Lung carcinomas are currently the leading cause of cancer-related mortality worldwide due to its' poor prognosis, multidrug resistance (MDR) and low survival rate [17-19]. Over $85 \%$ of lung cancer cases are related to non-small-cell lung cancer (NSCLC) and the major histopathological subtypes are adenocarcinomas, squamous cell carcinomas and large cell carcinomas [18,20-24]. Oncogenic K-RAS mutations in human NSCLC (10-30\%) have gained resistance to chemotherapy and radiation [25-27]. Although K-RAS mutations are well known, there is a lack of effective therapeutic options available for K-RAS driven NSCLC. ${ }^{25}$ Severe side effects, multidrug resistance and poor survival outcomes are the limitations of current NSCLC therapies [28,29], indicating the urgency of developing an effective therapeutic for its treatment.

Targeted delivery of two or more therapeutic drugs to tumor sites is showing promise for the effective treatment of cancer [30]. Such combination therapies enable inhibition of multiple tumorigenesis pathways while overcoming severe side effects and multidrug resistance. Considering the importance of combination therapy, a new drug combination, LSL and ganetespib (GT) is proposed in this study. We reasoned that GT is a second generation Hsp90 inhibitor, which leads to the degradation of major client proteins, disrupts important signaling cascades responsible for cell proliferation and survival of tumor [31-34]. GT is also believed to have antineoplastic activity and has shown promise for the treatment of NSCLC [35-37]. In addition, the use of nanotechnology-based drug delivery system is an emerging area of interest for increased payloads, biocompatibility, and targeted delivery of chemotherapeutic drugs, resulting in minimal side effects. Recent studies indicate the huge potential of various nanoparticles as drug carriers in cancer therapy, including targeted drug delivery, diagnosis, imaging, and treatment [38-43]. Among others, cerium oxide nanoparticles (NC) has received considerable attention due to its excellent catalytic and antioxidant properties with different cell systems. As an antioxidant, many reports are available indicating its cytotoxicity towards cancer cells while providing protective effects in certain neurodegenerative disorders [44-49].

Herein, we report a new combination therapy approach for the effective treatment of NSCLC (A549 cells). The blend of chemotherapeutic drugs, LSL and GT, are encapsulated within folate conjugated nanoceria (FNC) to minimize their off-target effects. Additionally, the anti-oxidative nature of nanoceria facilitates for the survival of healthy tissues, while generating in situ chronic oxidative stress within tumor cells reducing their viability [50,51]. This property of NC combined with the synergistic therapeutic actions where LSL and GT functions to inhibit HDAC and Hsp90 signaling pathways was evaluated as a treatment of NSCLC (Figure 1) [52,53]. The therapeutic effects of this combination therapy were examined by performing various cell-based assays including cell viability, enhanced ROS, apoptosis and necrosis, migration and HDAC assays. Together, findings from this study provide clinically acceptable strong support for the developed NSCLC treatment that supports its further investigation as a candidate therapeutic option.

\section{Results and Discussion}

\section{Synthesis and Characterizations of Functional Cerium Oxide Nanoparticles}

Carboxylic acid group functionalized cerium oxide nanoparticles (PNC 1, Scheme 1) were synthesized using a previously reported water-based alkaline precipitation method [54]. In summary, cerium nitrate salt was used as the source of nanoceria, whereas polyacrylic acid (PAA) was used as the stabilizing agent. The synthesized yellow PNC solution was then centrifuged to discard larger sized PNC particles. The resulting supernatant was dialyzed using a dialysis membrane (MWCO 6-8 kDa) to remove unreacted reagents including free PAA and $\mathrm{NH}_{4} \mathrm{OH}$ from PNC. The effective coating of $\mathrm{NC}$ by PAA was confirmed by vacuum drying and performing FT-IR analysis. As shown in Figure 2A (red line), the presence of a band at $1685 \mathrm{~cm}^{-1}$ confirmed the PAA coatings on PNC. The PAA coating results in a stable, water dispersible nanoparticle for efficient drug encapsulation. Furthermore, the surface carboxylic acid groups allow conjugation of various receptor-targeting molecules 
for targeted delivery. The average size (diameter) and overall surface charge (zeta potential) of PNC, determined by dynamic light scattering method, were $\mathrm{D}=56 \mathrm{~nm}$ (black line, Figure 2B) and $\zeta=-25 \mathrm{mV}$ (Figure 2C), respectively. The transmission electron microscopic (TEM) analysis showed the formation of highly dispersed cerium oxide core of $22 \pm 3 \mathrm{~nm}$ (Inset, Figure 2B).

Conjugation of folic acid on the surface of nanoceria was carried out using "click" chemistry. First, the propargylated NC (3) and azidefunctionalized folic acid were synthesized following

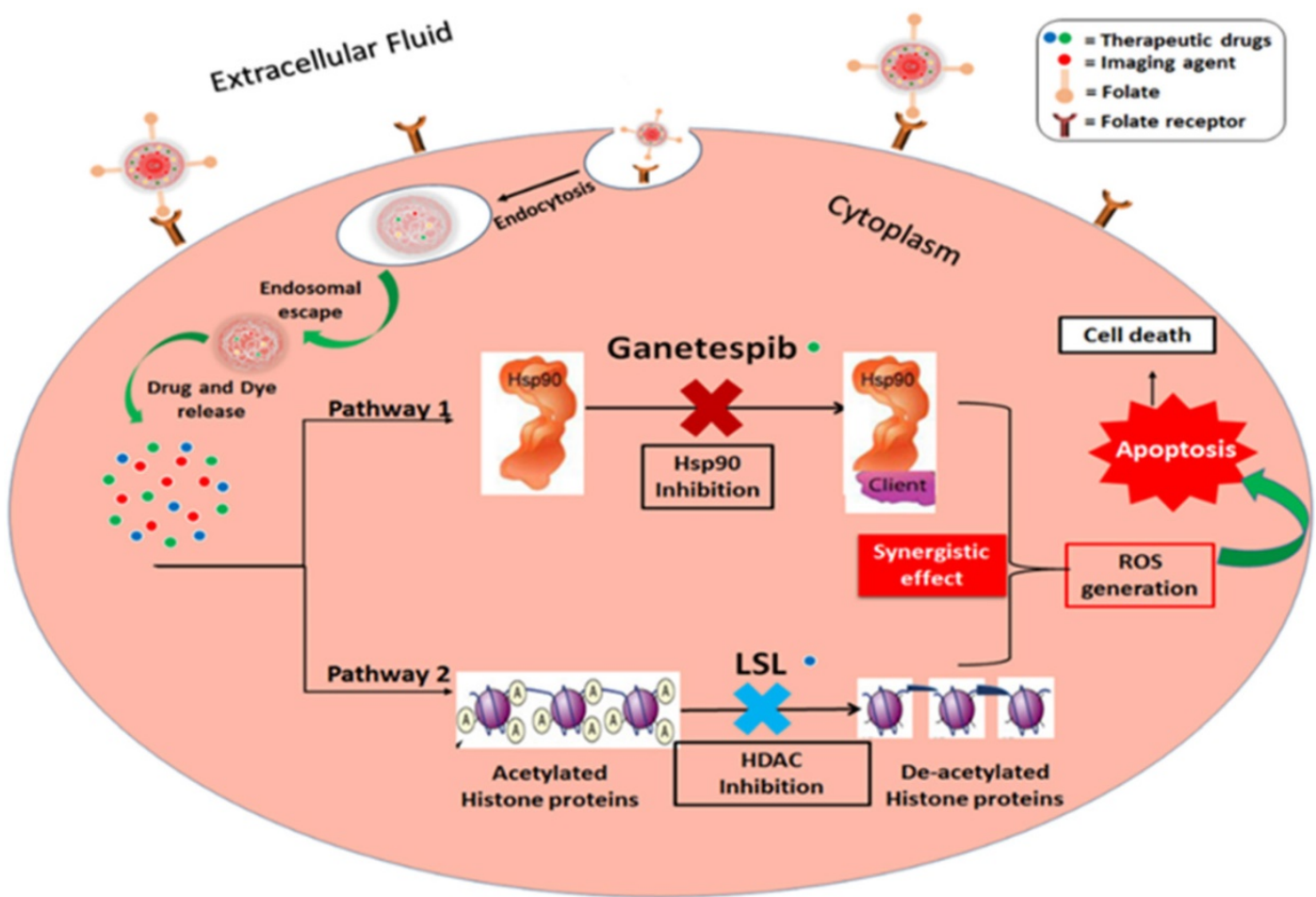

Figure 1. Schematic representation of the proposed mechanisms of action of the combination of ganetespib and lactonic sophorolipids for NSCLC treatment.
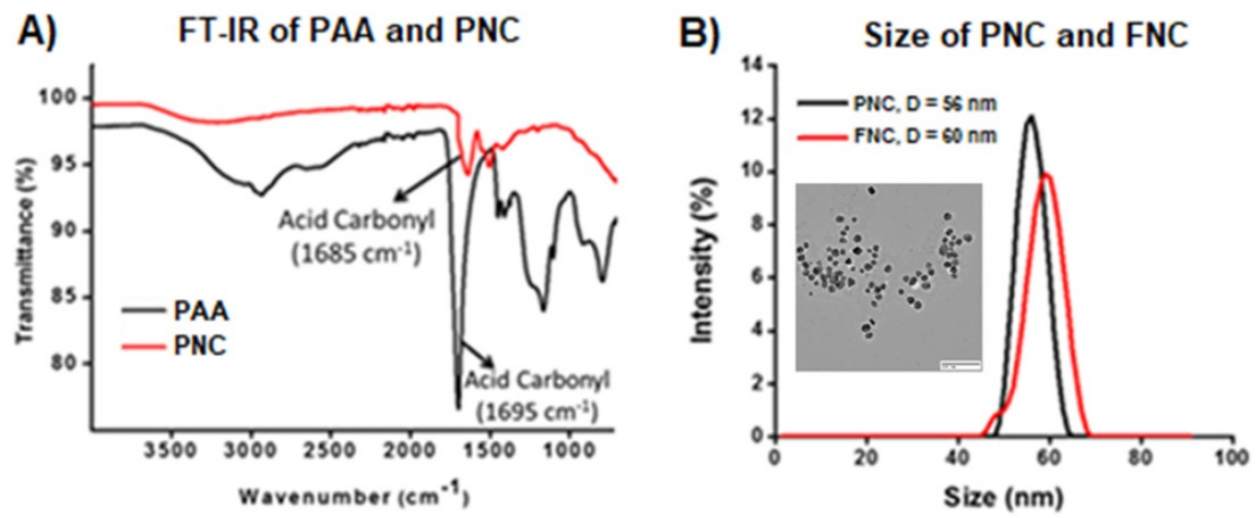
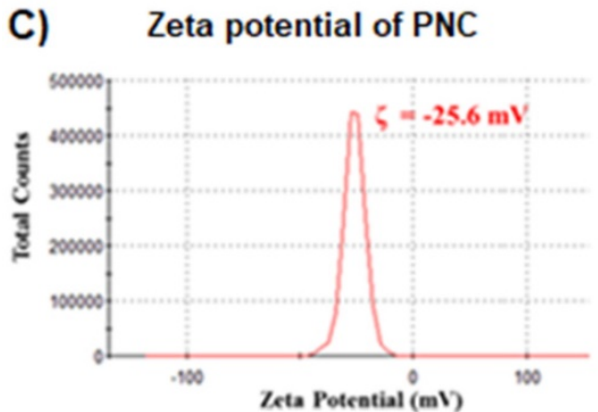

D)

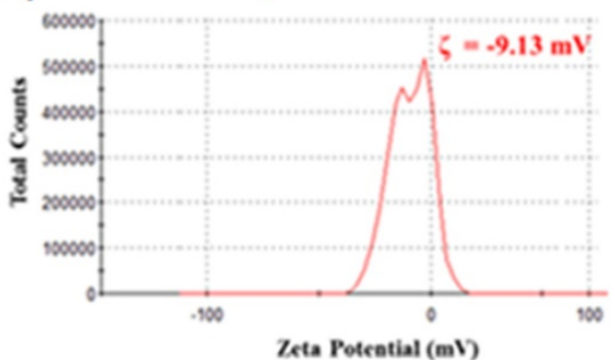

Figure 2. A) The presence of PAA coating of PNC particles was confirmed by the presence of an acid carbonyl band at $1685 \mathrm{~cm}^{-1}$ in the $\mathrm{FT}-\mathrm{IR}$ spectrum. B) Dynamic light scattering (DLS) determined average diameter of PNC $(56 \mathrm{~nm})$ and FNC $(60 \mathrm{~nm})$, Inset: TEM image of PNC (scale bar: $100 \mathrm{~nm})$ and zeta potentials of C) PNC and D) FNC. 
previously published methods $[14,15]$. Next, in the presence of a $\mathrm{CuI}$ catalyst, the conjugation of propargylated NC $\left(3,2.0 \times 10^{-3} \mathrm{~mol}\right)$ and azide-functionalized folic acid $\left(2.0 \times 10^{-2} \mathrm{~mol}\right)$ was performed in phosphate buffered saline (PBS) solution at $\mathrm{pH} 8.0 .^{14,15}$ The synthesized FNC (4 and 5, $1.5 \times 10^{-3} \mathrm{~mol}$, Scheme 1) was purified by dialysis (MWCO 6-8 kDa). The successful folate conjugation was confirmed by performing FT-IR experiments and compared with FT-IR spectra of PNC and PAA polymer. As seen in SI Figure S1, compared to PNC, the FT-IR spectrum of FNC showed bands at 1690, 1605, 1490, 1411 and $3054 \mathrm{~cm}^{-1}$, which confirmed for the presence of folic acid in FNC. This was further confirmed by performing UV-Vis spectroscopy (Figure 3). Next, the fluorescent lipophilic cationic indocarbocyanine dye DiI $(1.0 \mu \mathrm{M})$ was selected for optical imaging due to its higher extinction coefficient $\left(\varepsilon>125000 \mathrm{~cm}^{-1} \mathrm{M}^{-1}\right)$, red fluorescence emission $\left(\lambda_{\max }\right.$ $=585 \mathrm{~nm}$ ) and excellent photostability [55]. This red dye was encapsulated by solvent diffusion method to formulate DiI-encapsulated FNC $\left(4,1.0 \times 10^{-3} \mathrm{~mol}\right)$ which provided a positive control for optical imaging and treatment monitoring of cancer [15]. The DiI dye loading was effective and the encapsulation efficiency (EE $\left.E_{D i I}\right)$ was $87 \%$. Individual drug encapsulations $\left(\mathrm{EE}_{\mathrm{LSL}}=77 \%, \mathrm{EE}_{\mathrm{GT}}=81 \%\right)$ and co-encapsulation of the therapeutic drug combination of LSL and GT $\left(E_{\mathrm{LSL}+\mathrm{GT}}=75 \%\right)$ in folate nanoceria $\left(5,1.0 \times 10^{-3} \mathrm{~mol}\right)$ was performed using similar modified solvent diffusion method. As described, in the solvent diffusion method of encapsulation, dye and drugs are encapsulated in the polymer (PAA) coatings of the nanoceria, instead of chemical conjugation. Hydrophobic-hydrophobic and intermolecular forces are the major driving forces for this encapsulation. Finally, these preparations were dialyzed for purification and stored at $4{ }^{\circ} \mathrm{C}$ for further characterizations. The overall diameter and surface charge of functional FNC (5), determined by DLS, are $60 \mathrm{~nm}$ and $-9.13 \mathrm{mV}$, respectively (Figure 2B and 2D). The successful encapsulation of DiI dye in the polymer coating of FNC was confirmed by UV-Vis absorbance and fluorescence spectroscopy. Absorbance spectra of dye encapsulated FNC (Figure 3A and 3C) confirmed the presence of both folic acid $\left(\lambda_{\mathrm{abs}}=360 \mathrm{~nm}\right)$ and DiI dye $\left(\lambda_{\mathrm{abs}}=574 \mathrm{~nm}\right)$. This was further confirmed by their corresponding fluorescence spectra (Fol: $\lambda_{\mathrm{em}}=395 \mathrm{~nm}$; DiI: $\lambda_{\mathrm{em}}=585$ nm, Figure 3B and 3D). The overall size and fluorescence emission of these drug-loaded NC (5) preparations were found to be comparable over time (over 12 months), indicative of aqueous stability of functional NC in serum and PBS at physiological $\mathrm{pH}$.
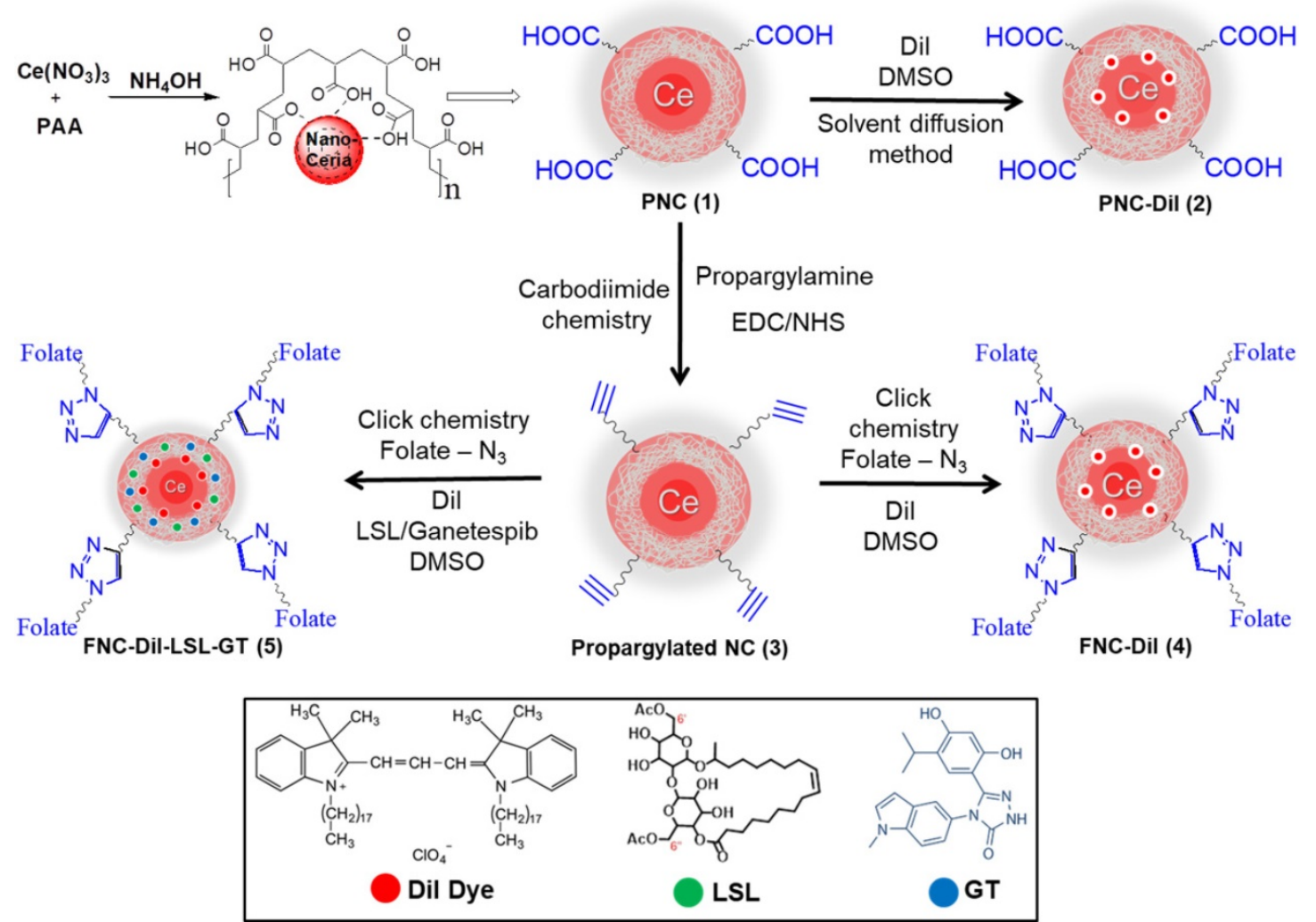

Scheme 1. Schematic representation of the synthesis of functional NC. Polymer-coated nanoceria (PNC 1) was synthesized using an alkaline precipitation method. Propargylated NC (3) was synthesized using carbodiimide chemistry and the "click" chemistry was used to functionalize $\mathbf{3}$ with folic acid (FNC, 4 and $\mathbf{5}$ ). Solvent diffusion method was used for the encapsulation of theranostics. 


\section{Cargo release experiments}

To evaluate drugs and dye release kinetics of NC-based delivery system under external conditions representing the microenvironment of a tumor, we performed DiI dye release experiments under esterase enzyme and acidic $\mathrm{pH}$ conditions ( $\mathrm{pH}$ 6.0). We have selected DiI dye as a representative cargo for this release study due to its strong fluorescence emission at $585 \mathrm{~nm}$, whereas both the drugs LSL and GT are weak chromophores. As seen previously [31], the PAA polymer coatings of NC are disrupted in acidic

\section{Spectrophotometric characterizations of functional nanoceria}
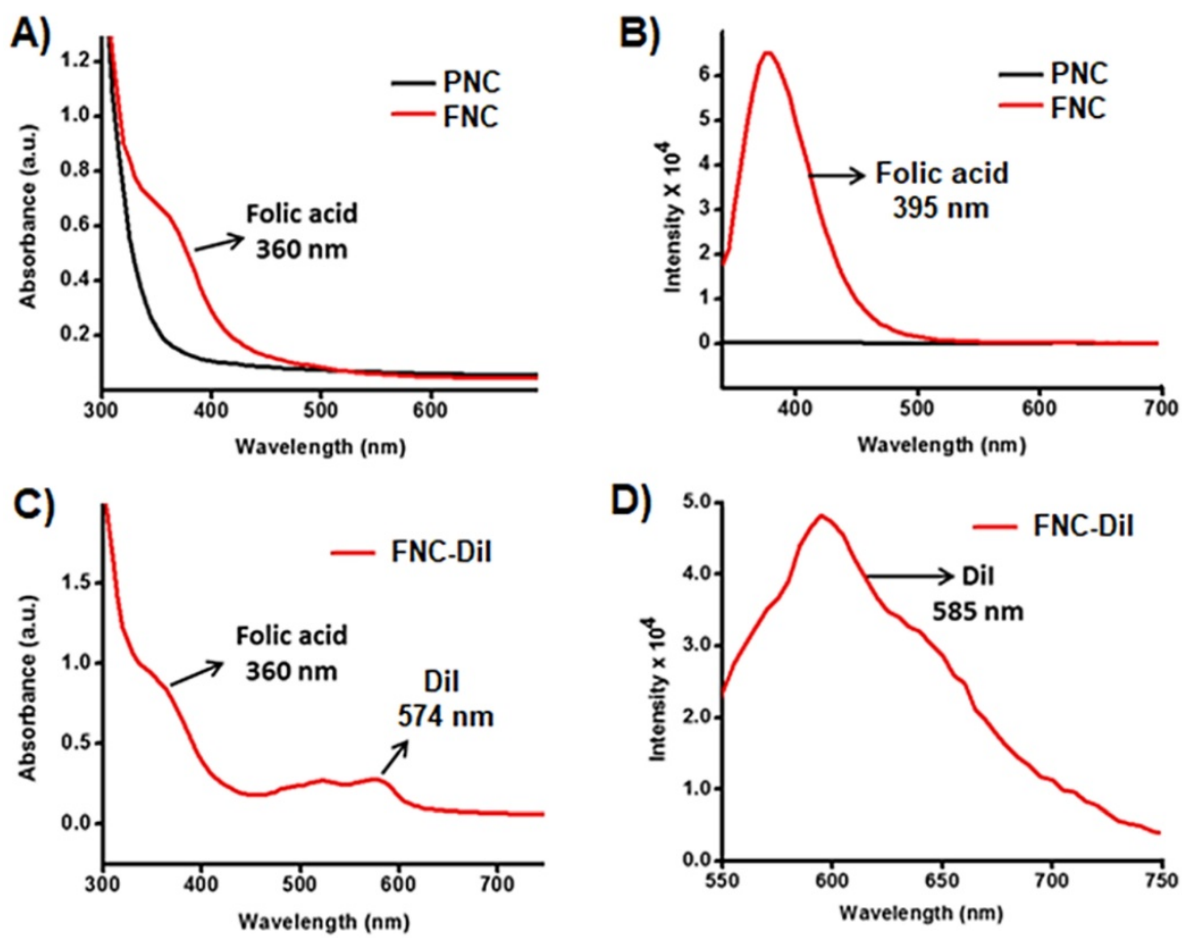

Figure 3. Characterization of functionalized NC. A) UV-Vis absorption and B) fluorescence emission spectra recorded from PNC (back line) and FNC (red line), indicated for the effectiveness of "click" chemistry. C) UV-Vis absorption spectrum of folate nanoceria and D) fluorescence emission at $\lambda_{\mathrm{em}}=585 \mathrm{~nm}$, confirmed for the successful encapsulation of Dil dye in FNC.
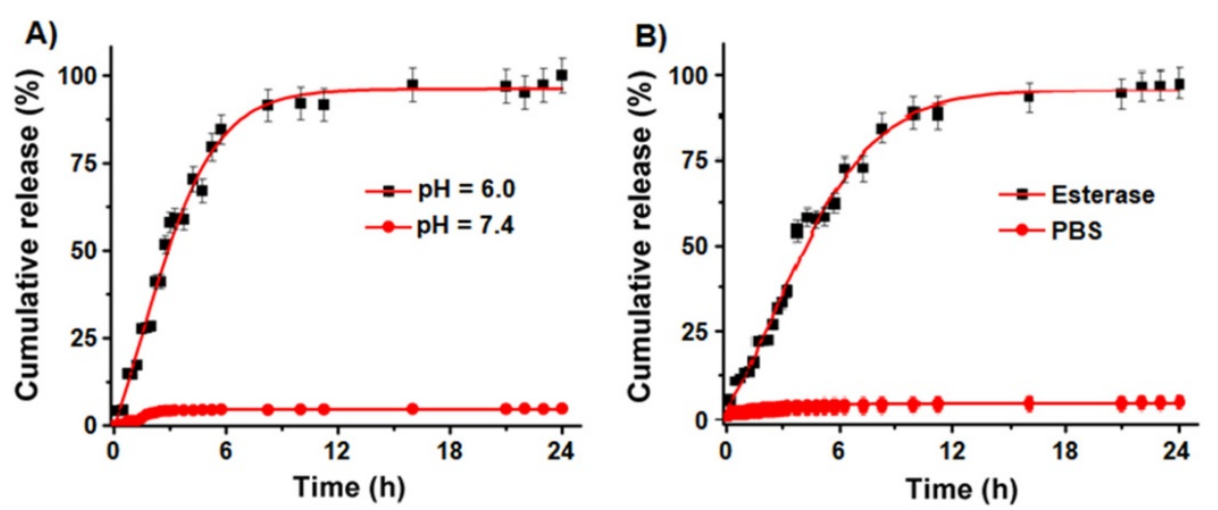

Figure 4. Controlled cargo release profiles of FNC-Dil-LSL-GT using dynamic dialysis method. (A) Controlled release of Dil dye from FNC with time in acidic $\mathrm{pH}(\mathrm{pH} 6.0)$ was observed and about $80 \%$ of drug is released within $6 \mathrm{~h}$ of time. However, minimal release was seen at normal pH $(\mathrm{pH}$ 7.4). (B) Similarly, release of Dil dye in esterase enzyme (1.0 mM) was studied using fluorescence spectrometer $\left(\lambda_{\mathrm{em}}=585 \mathrm{~nm}\right)$ where fluorescence maxima increased as the dye releases with time. However, there is no or minimal release of dye observed (red lines) at normal pH conditions. environment by hydrolyzing the coordinate bonding etween PAA polymer carbonyl groups and cerium incubating in the presence of esterase enzyme (1.0 ) from porcine liver. Time dependent study of at $585 \mathrm{~nm}$ using a microplate reader. The cumulative release of Dil dye at $\mathrm{pH} 6.0$ (Figure 4A) indicated for a burst release of dye $(80 \%)$ within $6 \mathrm{~h}$ of incubation and then the release was stabilized with time. The dye release was comparably slower when incubated in esterase enzyme $(1.0 \mathrm{mM})$ as seen in Figure $4 \mathrm{~B}$. In contrast, at $\mathrm{pH} 7.4$ no detectable release of dye was observed, which indicated for the stability of our cargosloaded NC in physiological conditions. These results confirm that our NC drug delivery system releases the cargos within the acidic environment of tumor cells and are stable at normal $\mathrm{pH}$.

\section{Cell viability assay (MTT assay)}

To assess the therapeutic efficacy of FNC containing Dil as well as GT and/or LSL (FNC-Dil, FNC-DiI-GT, FNCDil-LSL and FNC-Dil-LSL-GT, $\left.35 \mu \mathrm{L}, 1.0 \times 10^{-3} \mathrm{~mol}\right)$, a series of cytotoxicity experiments were conducted in a time dependent manner using two different cell lines, A549 (NSCLC, folatepositive) and $\mathrm{CHO}$ (Chinese hamster ovary, folate-negative) cells. Cells seeded in a 96-well plate (2500 cells/well), were incubated with functional NC $\left(35 \mu \mathrm{L}, 1.0 \times 10^{-3} \mathrm{~mol}\right)$ at $37^{\circ} \mathrm{C}$. The cell viability was monitored by the MTT assay. Nanoceria by itself without drugs (4, FNC-DiI) showed minimal toxicity to both the cancer and normal cells. Incubation with LSL (FNC-DiI-LSL) alone resulted in about $40 \%$ NSCLC cell death 
at $24 \mathrm{~h}$. By combining LSL and GT in FNC (FNC-DiI-LSL-GT), cell death increased 2-fold reaching $80 \%$ by $24 \mathrm{~h}$ and over $90 \%$ by $48 \mathrm{~h}$. This result indicated for the anticancer property of LSL, which was successfully synergized by GT, where both the drugs combination (FNC-DiI-LSL-GT) showed more than $80 \%$ of cell death within $24 \mathrm{~h}$ of incubation, and over $90 \%$ within $48 \mathrm{~h}$ of incubation (Figure 5A). In contrast, substantial lower cell death was observed when $\mathrm{CHO}$ cells were incubated with drug(s) loaded FNC (Figure 5B) since $\mathrm{CHO}$ cells lack folate receptors. That is, for $48 \mathrm{~h}$ incubations of $\mathrm{CHO}$ cells with FNC-DiI-LSL-GT, cell death reached $15-20 \%$. This demonstrates the therapeutic efficacy of LSL and importance of folate receptor that enables the targeting of cancer cell lines, thereby decreasing its cytotoxicity to normal cells. Together, the targeted delivery of FNC-DiI-LSL-GT might prove valuable in overcoming the MDR to treat undruggable NSCLC and other tumors.

\section{Fluorescence microscopy}

To interrogate receptor-mediated FNC internalizations and cargo release in living cells, we performed cellular internalization experiments and recorded a set of fluorescence microscopic images to visualize the effect of therapeutic drugs release. We hypothesized that FNC would target tumors overexpressing folate receptors. Consequently, uptake of FNC would occur to a great extent by cancer cell lines relative to normal cells decreasing cancer drug toxicity to healthy cells. When carboxylated NC encapsulated with DiI dye (2, PNC-DiI, $1.0 \times 10^{-3} \mathrm{~mol}$, Figure 6A-6D) was incubated with A549 cells for $24 \mathrm{~h}$, low or no internalization was observed. This is due to the lack of folate ligands on the surface of PNC. However, A549 cells incubated with DiI dye encapsulated FNC (4, FNC-DiI) for $24 \mathrm{~h}$ resulted in
A) MTT Assay with A549 cells (Folate +)

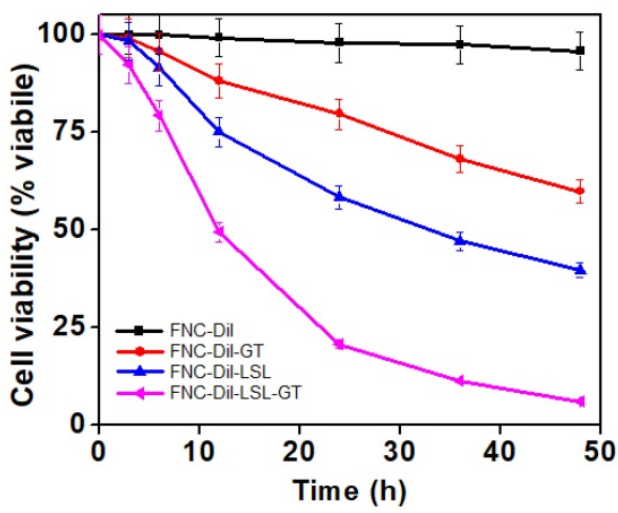

B) MTT Assay with CHO cells (Folate -)

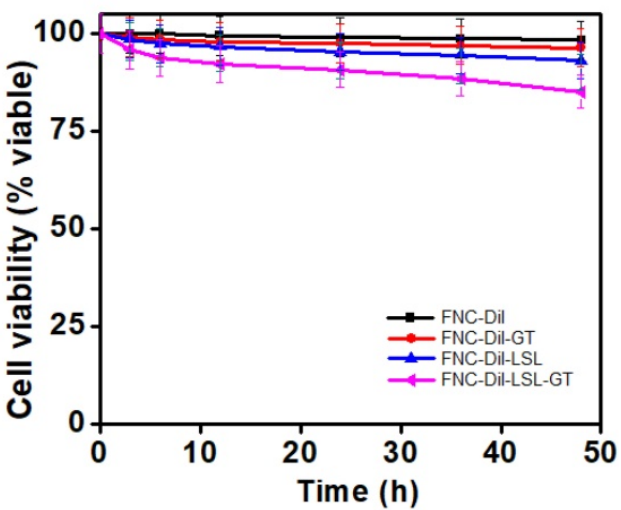

Figure 5. Determination of cytotoxicity of formulated folate nanoceria (FNC) using the MTT assay. A) More than $80 \%$ cell death occurred within $24 \mathrm{~h}$ when incubated with FNC loaded with both LSL and GT, whereas only $20-40 \%$ toxicity was observed when single drug was delivered. B) Lower toxicity was observed when drug-loaded FNC was incubated with CHO cells (FR -), suggesting that the folate receptor enabled selective uptake of drugs-carrying FNC by the cancer cell line. effective internalization of FNC. This was observed due to intracellular DiI dye release that resulted in a red fluorescence cytoplasm (Figure 6E-6H). To further illustrate the folate receptor-mediated internalizations and treatment, A549 cells were incubated with FNC containing encapsulated Dil, LSL and GT (FNC-DiILSL-GT). After incubation for $24 \mathrm{~h}$, observation of the cell morphology showed that cells had ruptured (Figure 6I-6L). These results confirm the effective receptor targeting and drug delivery to cancer cells. When $\mathrm{CHO}$ cells were incubated with DiI dye encapsulated FNC, minimal internalization was observed due to the lack of folate receptors on the surface of $\mathrm{CHO}$ cells (normal, healthy cells, Figure 6M-6P). This demonstrates that, for the selected cell lines studied herein, FNC has much higher affinity for the cancer cell line than the normal cell line. This may enable the tuning of drug doses that induce death in cancer cells while minimizing deleterious effects to normal cell lines. Taken together, these results indicate the potential of the developed FNC platform for targeted drug delivery to cancer cells.

\section{Cytosolic reactive oxygen species (ROS) detection assay}

An alternative approach to achieve better anticancer therapy is to selectively enhance reactive oxygen species (ROS) in cancer cells. The generation of ROS in the cell was determined by dihydroethidium (DHE) fluorescence, a dye which is oxidized to 2-hydroxyethidium in the presence of intracellular ROS resulting in red fluorescence. Previous studies have shown that ROS generation via HDAC inhibition as one of the mechanisms by which LSL exerts its antitumor activity [35-39]. To determine, whether GT complements ROS production by LSL, A549 cells were treated with LSL and GT encapsulated within FNC $\left(5,1.0 \times 10^{-3} \mathrm{~mol}\right)$. Briefly, A549 cells were seeded into 12-well plates $(10,000$ cells/well) and incubated with four different functional nanocarriers: (1) FNC without drug, (2) FNC with GT alone (FNC-GT), (3) FNC with LSL (FNC-LSL), and (4) FNC with both LSL and GT (FNC-LSL-GT). After $6 \mathrm{~h}$ incubations, the cells were washed and stained with the cytosolic cell permeable probe dihydroethidium (DHE) for $30 \mathrm{~min}$. As shown in 
Figure 7A-7B, the cells treated with FNC exhibited minimal fluorescence due to limited ROS stress. FNC with encapsulated GT showed a moderate amount of fluorescence corresponding to the ROS stress induced by the drug (Figures 7C-7D). In contrast, when the A549 cells were incubated with FNC-LSL, the increased fluorescence intensity observed corresponds to an elevated ROS level (Figures 7E-7F). This may be corresponding to the higher cytotoxicity of LSL via HDAC inhibition pathway [45-49]. When incubated with both LSL and GT (FNC-LSL-GT), the observed fluorescent intensity was further increased relative to FNC-LSL corresponding to the generation of even higher ROS levels (Figure 7G-7H), this further indicated that GT complemented the therapeutic efficacy of LSL by triggering ROS generation. In addition, the formation of ROS was determined by calculating the fluorescence intensities obtained from each fluorescence microscopic image using Image software and the results relative $\mathrm{H}_{2} \mathrm{O}_{2}$ incubations are displayed in Figure 8. From this analysis it is evident that the additive fluorescent intensities of FNC-GT and FNC-LSL is $1.35 \times 10^{4}$ whereas the fluorescent intensity of FNC-LSL-GT is $2.40 \times 10^{4}$. This result demonstrates that there is a synergistic effect on ROS generation in A549 cells by combining GT and LSL.

\section{Apoptosis and necrosis detection assays}

Increased ROS production often correlates with apoptosis, a form of programmed cell death. Experiments were then conducted to further elucidate the correlation between ROS generation and the induction of apoptosis. A549 cells were incubated with FNC, FNC-GT, FNC-LSL and FNC-LSL-GT $\left(1.0 \times 10^{-3} \mathrm{~mol}\right)$ for $24 \mathrm{~h}$. Apoptotic and necrotic cells were differentiated based on their morphology and by fluorescence microscopy. Upon staining with Annexin V-FITC and ethidium homodimer III, the apoptotic and necrotic cells exhibited green and red fluorescence, respectively. This is due to that, with increased ROS levels, cells undergo various morphological and biochemical changes including translocation of phosphatidylserine (PS), leading to the induction of apoptosis. As demonstrated in Figure 9A-9B, FNC shows few apoptotic cells, which is related to the redox nature of FNC. Annexin V and ethidium homodimer stained microscopic images indicated that treatment with FNC-GT (Figure 9C-9D) and FNC-LSL (Figure 9E-9F) results in many green spots and fewer red spots that correlate with apoptotic and necrotic cells, respectively. Incubation of A549 cells with FNC-LSL-GT results in a dramatic

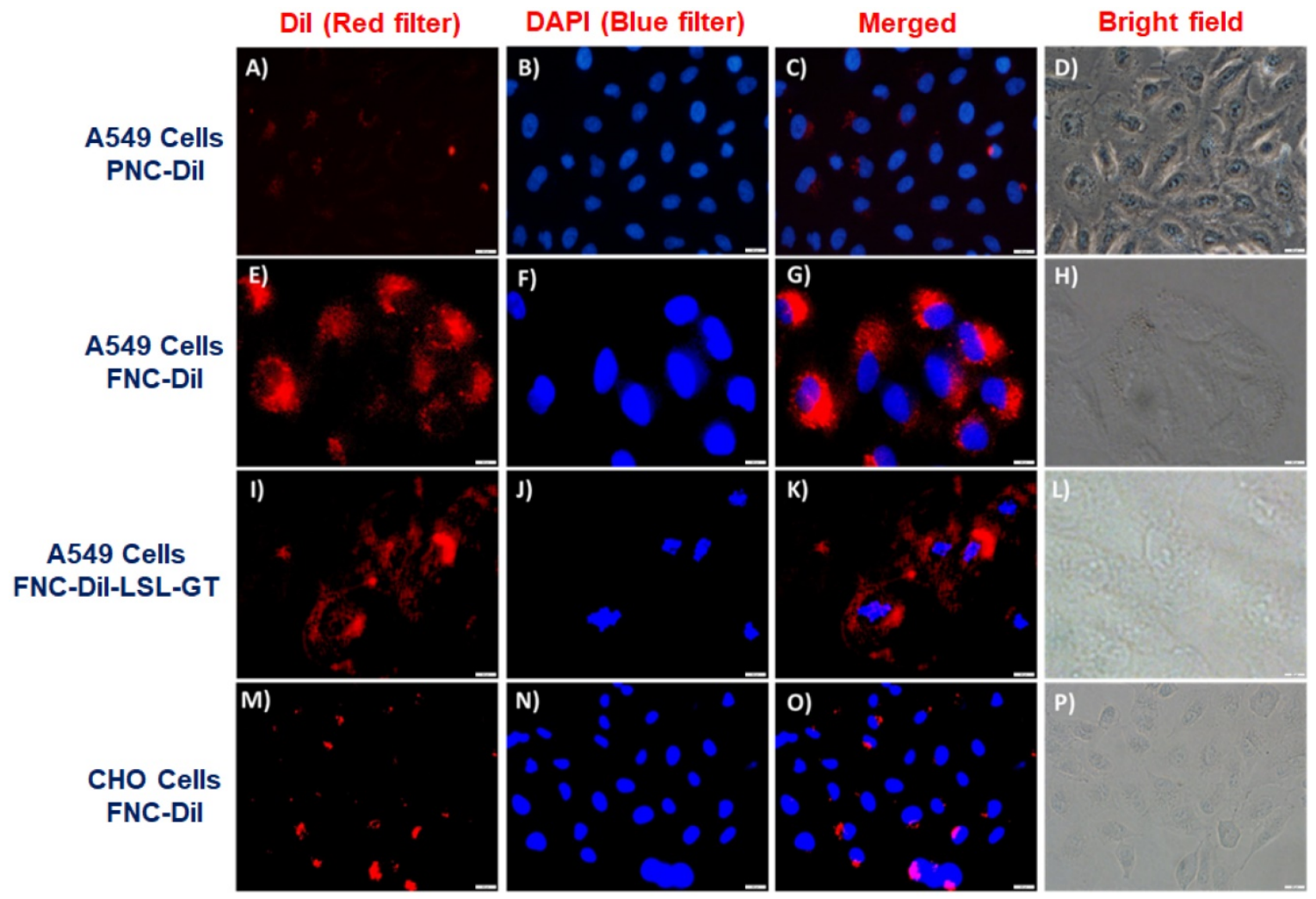

Figure 6. Representative fluorescence microscopic images for the in vitro internalizations, cellular imaging and treatment. Minimal internalization of carboxylated nanoceria was observed in A549 cells due to absence of the folate on the surface of NC (A-D, scale bar: $500 \mu \mathrm{m})$. Effective internalization of FNC was observed due to folate receptor-mediated endocytosis (E-F, scale bar: $200 \mu \mathrm{m})$. When FNC was loaded with both LSL and GT, a substantial amount of A549 cell death was observed at $24 \mathrm{~h}(\mathbf{I}-\mathrm{L}$, scale bar: $500 \mu \mathrm{m})$. In contrast, minimal internalization of FNC was observed in CHO cells due to the absence of folate receptors on their surfaces (M-P, scale bar: $500 \mu \mathrm{m}$ ). Nucleus stained with DAPI dye (blue). 
increase in apoptotic cells (Figure 9G-9H). Hence, a synergistic effect on induced apoptosis results by combining LSL and GT, leading to extensive loss in membrane integrity, and eventually leading to cell death.

\section{Migration and HDAC inhibition assays}

Metastasis is the deadliest aspect of cancer and remains the principal cause of death despite research aimed at restricting tumor growth and migration such as what occurs during K-RAS driven NSCLC. To assess whether combining LSL with GT within FNC can inhibit tumor cell migration, we performed trans-well migration assays. In these experiments, A549 cells were serum starved and incubated with FNC $\left(1.0 \times 10^{-3} \mathrm{~mol}\right)$ for $24 \mathrm{~h}$ by seeding in the upper invasion chamber. When incubated with FNC without the incorporation of LSL or GT, cells migrate from the invasion chamber to the lower feeder tray containing 10\% FBS (Control, Figure 10A). However, upon incubation with FNC-LSL-GT, there is a large decrease in the fluorescence intensity relative to the control that correlates with a large decrease in the migration ability of A549 cells (FNC-LSL-GT, Figure 10A). These results indicate that FNC-LSL-GT may play an important role in preventing the metastatic nature of NSCLC.

To assess the HDAC inhibition activity of LSL, and verify whether combining LSL and GT results in a synergistic effect, a fluorescent HDAC inhibition assay was performed. The positive control for HDAC inhibition consists of HeLa cells nuclear extract and results in the highest observed fluorescence intensity (Black line, Figure 10B). In contrast, the negative control Trichostatin A (TSA) results in nearly no fluorescence intensity corresponding to the absence of a HDAC enzyme (green line). FNC-LSL-GT and
FNC-LSL showed significant HDAC inhibition activity when incubated with A549 cells. However, the combination of LSL and GT did not result in a synergistic effect on HDAC inhibition. Together, the observation that FNC-LSL results in HDAC inhibition indicates that this molecule follows the HDAC inhibition pathway leading to apoptosis of NSCLC cells.

\section{Methods}

\section{Materials}

Cerium(III) nitrate hexahydrate $\mathrm{Ce}\left(\mathrm{NO}_{3}\right)_{3} \cdot 6 \mathrm{H}_{2} \mathrm{O}$, polyacrylic acid (PAA), ammonium hydroxide $\left(\mathrm{NH}_{4} \mathrm{OH}\right)$, folic acid, N-hydroxysuccinimide (NHS), 2(N-morpholino) ethanesulfonic acid (MES) sodium salt, tetrahydrofuran, acetonitrile, sodium azide, ethanol, isopropanol and propargylamine (PA) were purchased from Acros Organics and used without further purification. Near infrared dye (DiI-D282) was obtained from Life technologies. N, N'-dimethyl formamide (DMF) and dihydroethidium (DHE) dye was purchased from Science lab and Cayman chemicals, respectively. $\mathrm{N}, \mathrm{N}^{\prime}$-dimethyl sulfoxide (DMSO), esterase enzyme from porcine liver, 3-(4, 5-dimethylthiazol-2-yl) - 2, 5-diphenyltetrazolium bromide (MTT) and (1-ethyl-3-[3-(dimethylamino) propyl] carbodiimide hydrochloride) (EDC) were obtained from Sigma Aldrich and used as received. 4, 6-diamidino-2-phenylindole (DAPI-D1306) was purchased from Invitrogen. Dialysis membrane were received from spectrum laboratories. Paraformaldehyde and $\mathrm{H}_{2} \mathrm{O}_{2}$ were received from electron microscopy sciences. Fetal bovine serum (FBS) and 5X Annexin binding buffer were purchased from BD biosciences, whereas ganetespib, isopropyl alcohol, apoptosis and necrosis quantification kit
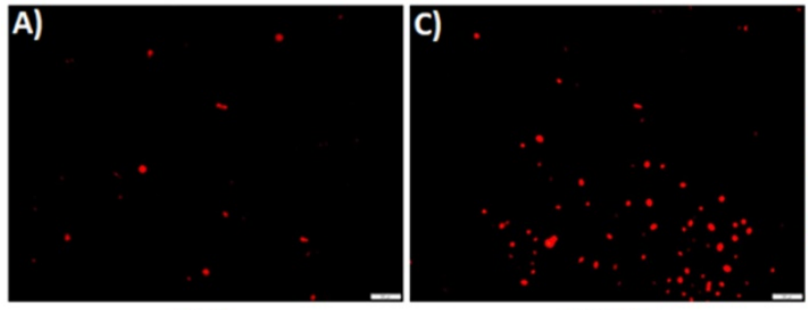

B)

FNC
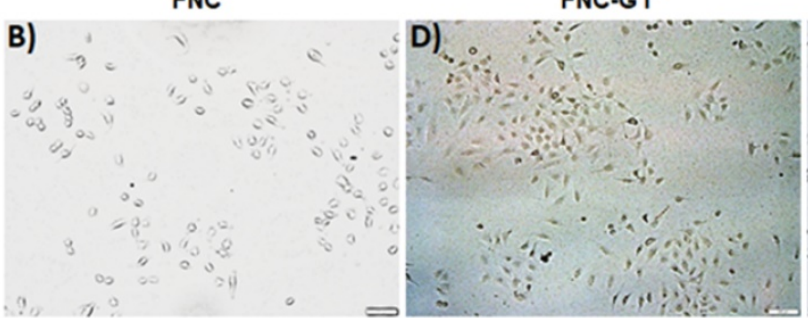

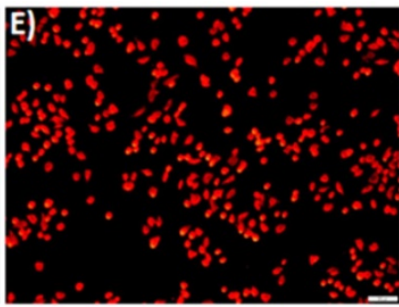

FNC-LSL

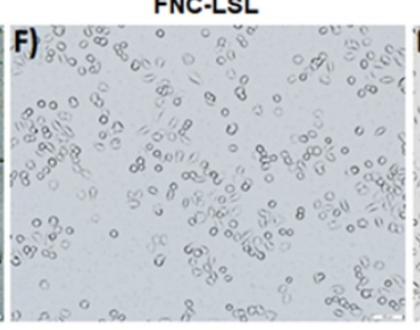

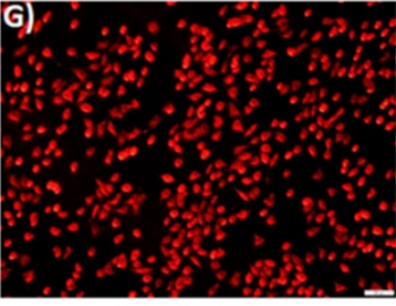

FNC-LSL-GT

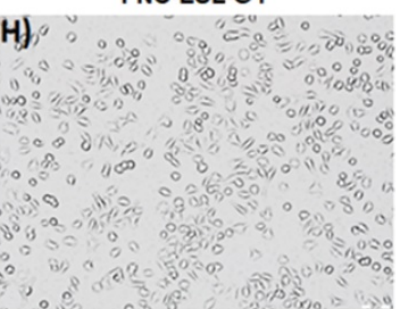

Figure 7. Determination of ROS generation in A549 cells when incubated with different nanoceria formulations. Increased fluorescence is due to increased ROS levels. Scale bar: $500 \mu \mathrm{m}$. 
(FITC-Annexin V, Ethidium homodimer III) were obtained from Biotium. Migration assay kit and HDAC inhibition fluorometric assay kit was obtained from Millipore and Biovision, respectively. The human lung carcinoma A549 cells (NSCLC) and Chinese hamster cells $(\mathrm{CHO})$ were obtained from ATCC (U.S.A). Dulbecco's modified eagle (DMEM) medium and Kaighn's modification of Ham's F12K cell culture medium were purchased from Corning.

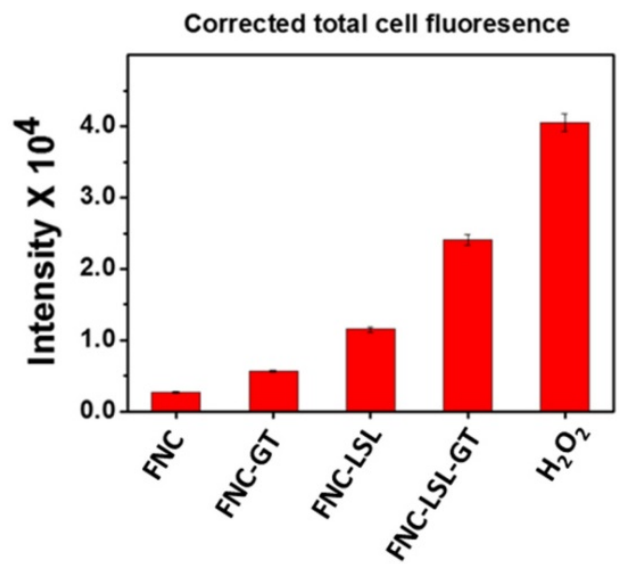

Figure 8. Quantification of ROS: Amount of ROS generation was quantified directly from the microscopic images using Image software. Fluorescence emission results for FNC-LSL-GT relative to FNC-LSL and FNC-GT demonstrate that combining LSL-GT results in a synergistic effect on ROS generation within A549 cells.

\section{Characterizations of functional nanoceria}

Fourier transform infrared spectroscopy (FTIR)

To verify the surface functionalities of synthesized FNC, FTIR studies were performed using a Perkin-Elmer's Spectrum Two. PAA-coated NC was air dried and the powdered nanoceria was collected. FT-IR spectra of dried PAA-coated NC and PAA polymer were recorded and compared to confirm the successful coating of PAA on the synthesized NC.
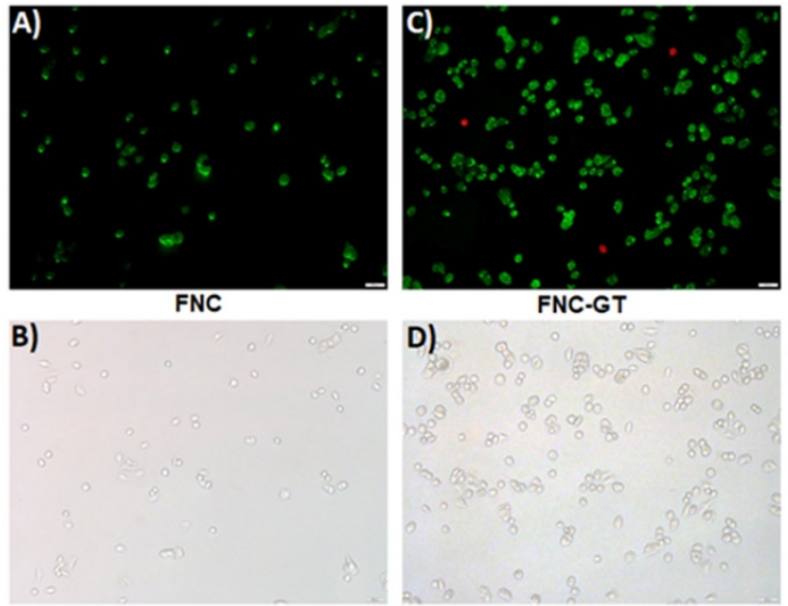

FNC-GT

D)

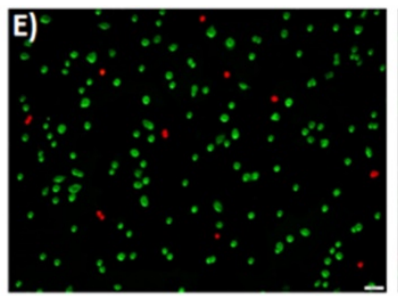

FNC-LSL

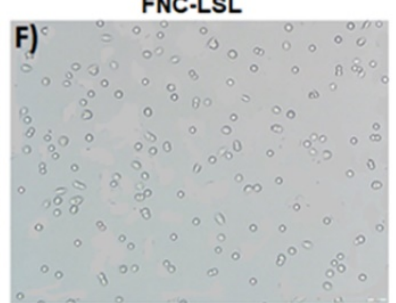

\section{Dynamic light scattering (DLS)}

The average size distribution and surface charge of functional nanoceria were obtained using dynamic light scattering (DLS) technique. Malvern's NANOZS90 zetasizer was used for DLS studies. Typically, $1.0 \mathrm{~mL}$ of functional nanoceria was taken in a cuvette and measured for size using standard procedure set in Malvern Zetasizer. For measuring zeta potential, the sample was diluted with DI water and is carefully loaded in electrode without air bubble and the zeta potential was recorded.

\section{Spectrophotometric analysis}

UV-Vis and fluorescence spectroscopic studies of FNC were recorded using TECAN's infinite M200 PRO high throughput plate reader to confirm the successful conjugation of folic acid ligands on the surface of nanoceria for targeted drug delivery. Similar studies were also performed for confirming the presence of DiI dye in nanoceria for optical imaging. Procedure involves the addition of $75 \mu \mathrm{L}$ of suspension in Thermo-Fisher 96 well plate and measuring the absorbance and fluorescence at 300-800 $\mathrm{nm}$ and $585 \mathrm{~nm}$ wavelengths, respectively.

\section{In vitro cell culture and fluorescence microscopy}

Lung carcinoma A549 cells were maintained in a 10\% FBS containing DMEM medium supplemented with $1 \%$ penicillin-streptomycin antibiotic, whereas, $\mathrm{CHO}$ cells were propagated in $10 \%$ FBS containing Ham's F12K media containing $1 \%$ penicillinstreptomycin antibiotic. Cells were grown under 5\% $\mathrm{CO}_{2}$ atmosphere at $37^{\circ} \mathrm{C}$ in a humidified incubator. Fluorescence and bright field images of the cells were taken using Olympus IX73 fluorescence microscope.

Figure 9. Detection of apoptotic and necrotic cell death by fluorescence microcopy using annexin V-FITC and ethidium homodimer III. A-B) Healthy cells exhibit few green fluorescence spots that correlates with the low oxidative nature of FNC. C-F) Cells incubated with FNC-LSL or FNC-GT show a substantial increase relative to FNC in the number of green fluorescence spots that correlate with induction of apoptosis. G-H) The combined encapsulation of GT and LSL with FNC results in a dramatic increase in green fluorescent spots with relatively fewer red fluorescence that correlates with a high extent of late apoptotic cells and fewer necrotic cells. Scale bar: $500 \mu \mathrm{m}$. 

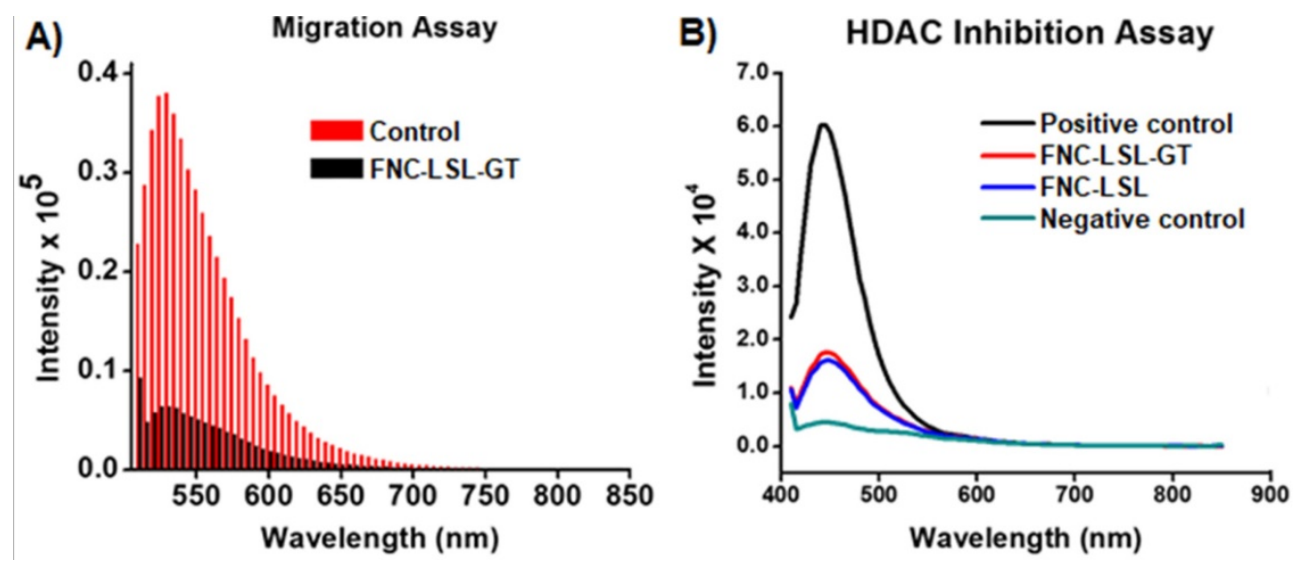

Figure 10. A) Determination of the anti-migratory effect of FNC-LSL-GT on highly metastatic lung cancer cells via the migration assay. Results indicate significant migration of cells when treated with FNC without drug incorporation (red lines). In contrast, FNC-LSL-GT (black lines) results in a dramatic decrease in the ability of the cells to migrate. B) Assessment of inhibition of histone deacetylase (HDAC) by lactonic sophorolipids (LSL) in comparison with positive and negative controls. As depicted, the LSL drug showed significant effect on HDAC inhibition when compared with the negative control, while GT showed minimal effect on HDAC inhibition.

\section{Synthesis of poly (acrylic acid)-coated nanoceria (1, PNC)}

The synthesis of PAA-coated NC was performed following a previously published alkaline-based solvent precipitation method [15], where the cerium oxide nanoparticles were precipitated from a solution of ammonium hydroxide containing cerium salt and PAA. Briefly, solution A: cerium nitrate $(0.9 \mathrm{~g})$ in 2.5 $\mathrm{mL}$ of DI water, solution B: PAA $(0.9 \mathrm{~g})$ in $10 \mathrm{~mL}$ of DI water. Ammonium hydroxide $(30 \mathrm{~mL})$ was taken in a beaker, stirred at room temperature and solution $\mathrm{A}$ was added to it followed by the addition of solution $B$. A change of color from colorless to brown within 5 min of stirring was observed and finally deep yellow after $24 \mathrm{~h}$, indicating the preparation of stable nanoceria. The reaction mixture is centrifuged at 3000 rpm for $30 \mathrm{~min}$ to obtain smaller size nanoparticles. The solution was purified by dialysis using a dialysis bag of molecular weight cut-off (MWCO) of 6-8 $\mathrm{kDa}$ against Di water and finally with phosphate buffer saline (PBS, $\mathrm{pH}=7.4$ ) to remove ammonium hydroxide and free polymer and other reagents. Final concentration of PNC was adjusted to $3.0 \times 10^{-3} \mathrm{~mol}$.

\section{Synthesis of propargylated nanoceria (3): Carbodiimide chemistry}

Propargylated NC was synthesized by adding freshly prepared EDC $\left(15 \times 10^{-3} \mathrm{~mol}\right)$ solution to PNC $\left(3.0 \times 10^{-3} \mathrm{~mol}\right)$, followed by addition of NHS $\left(15 \times 10^{-3}\right.$ $\mathrm{mol})$ in $200 \mu \mathrm{L}$ of MES buffer $(0.1 \mathrm{M}), \mathrm{pH}=6.0$. The reaction mixture was incubated for $3 \mathrm{~min}$ at room temperature and then propargylamine $\left(15 \times 10^{-3} \mathrm{~mol}\right)$ dissolved in DMSO was added drop-wise and mixed. The reaction was continued for $3 \mathrm{~h}$ for completion at room temperature. The resultant propargylated NC was purified against PBS $(\mathrm{pH}=7.4)$ using a dialysis bag (MWCO 6-8 $\mathrm{kDa}$ ) to remove the unreacted reagents from the solution.

\section{Synthesis of folate conjugated NC (FNC, 4 and 5) using "click chemistry"}

To the solution of propargylated NC suspension $\left(3,2.0 \times 10^{-3} \mathrm{~mol}\right)$ in basic PBS solution ( $\left.\mathrm{pH} 8.0\right)$ and previously synthesized folate-azide $\left(\mathrm{Fol} \sim \mathrm{N}_{3}, 2.0 \times 10^{-2}\right.$ mol) [15], a catalytic quantity of CuI catalyst $\left(1 \times 10^{-3}\right.$ mmol) in DMF was added and incubated on a table mixer for overnight at room temperature. The resulting folate conjugated nanoceria (FNC) was purified by dialysis to remove unreacted materials. The purified product $\left(1.5 \times 10^{-3}\right) \mathrm{mol}$ was stored at $4{ }^{\circ} \mathrm{C}$ for further characterizations.

\section{Synthesis and characterization of LSL}

The synthesis of the natural glycolipid starting material LSL was performed following literature methods published by Gross's group [56,57]. Briefly, fed-batch fermentation of Candida Bombicola ATCC 22214 inoculum aliquots $\left(2-4 \times 10^{11}\right.$ cells $\left./ \mathrm{mL}\right)$ was conducted maintaining the oxygen transfer rate between 50 and $80 \mathrm{mM} \mathrm{O}_{2} / \mathrm{L} \mathrm{h}^{-1}$. The carbon sources was oleic acid ( $>95 \%$ purity) and glucose. $40 \mathrm{~g}$ of sunflower oil with high oleic acid content, $100 \mathrm{~g}$ of glucose, $10 \mathrm{~g}$ of yeast extract, and $1 \mathrm{~g}$ of urea in $1 \mathrm{~L}$ of water were used. This protocol provides product volumetric yields up to $350 \mathrm{~g} / \mathrm{L}$ (productivity 1.5 $\left.\mathrm{g} / \mathrm{L} \mathrm{h}^{-1}\right)$. The crude sophorolipids were extracted with ethyl acetate from the fermentation broth and dried under vacuum. The diacetylated lactonic sophorolipid, LSL, was purified by recrystallization from ethyl acetate/hexane (1:1) followed by flash chromatography using chloroform and methanol (10:1).

Yield $=83 \%$; Purity $=97 \% ; \mathrm{R}_{\mathrm{f}}\left[\mathrm{CHCl}_{3} / \mathrm{CH}_{3} \mathrm{OH}\right.$ 8:2] $=0.69 ;{ }^{1} \mathrm{H}$ NMR $\left(500 \mathrm{MHz}\right.$, DMSO- $\left.d_{6}\right):(\mathrm{ppm}) 1.12$ $\left(3 \mathrm{H}, \mathrm{d}, J=6.5 \mathrm{~Hz},-\mathrm{CH}_{3}\right), 1.16-1.60\left(20 \mathrm{H}, \mathrm{m},-\mathrm{CH}_{2}-\right)$, 
$2.00\left(10 \mathrm{H}, \mathrm{m},-\mathrm{CH}_{2} \mathrm{CH}=\mathrm{CHCH}_{2}-\right.$ and $\left.2 \mathrm{CH}_{3} \mathrm{CO}-\right), 2.30$ $\left(2 \mathrm{H}, \mathrm{t}, \mathrm{J}=6.7 \mathrm{~Hz},-\mathrm{CH}_{2} \mathrm{COO}-\right)$, 3.05-3.15 (2H, m, H-4 and $\left.\mathrm{H}-2^{\prime \prime}\right), 3.24\left(1 \mathrm{H}, \mathrm{t}, J=8.4 \mathrm{~Hz}, \mathrm{H}-2^{\prime}\right), 3.35-3,49(3 \mathrm{H}$, $\mathrm{m}, \mathrm{H}-3^{\prime}, \mathrm{H}-5^{\prime}$ and $\left.\mathrm{H}-3^{\prime \prime}\right), 3.60$ (2H, m, H-17 and H-5"), $3.98\left(2 \mathrm{H}, \mathrm{m}, \mathrm{H}-6^{\prime \prime}\right), 4.06(1 \mathrm{H}, \mathrm{dd}, \mathrm{J}=11.4$ and $7.0 \mathrm{~Hz}$, H-6'a), $4.22\left(1 \mathrm{H}, \mathrm{dd}, \mathrm{J}=11.9\right.$ and $\left.2.1 \mathrm{~Hz}, \mathrm{H}-6^{\prime} \mathrm{b}\right), 4.37$ $\left(1 \mathrm{H}, \mathrm{d}, J=7.7 \mathrm{~Hz}, \mathrm{H}-1^{\prime}\right), 4.51\left(1 \mathrm{H}, \mathrm{d}, J=7.8 \mathrm{~Hz}, \mathrm{H}-1^{\prime \prime}\right)$, $4.71\left(1 \mathrm{H}, \mathrm{t}, J=9.5 \mathrm{~Hz}, \mathrm{H}-4{ }^{\prime \prime}\right), 5.27(1 \mathrm{H}, \mathrm{d}, J=5.1 \mathrm{~Hz}$, $\mathrm{OH}), 5.30(4 \mathrm{H}, \mathrm{m},-\mathrm{CH}=\mathrm{CH}-$ and $\mathrm{OHs}), 5.43(1 \mathrm{H}, \mathrm{br} \mathrm{s}$, $\mathrm{OH}), 5.70(1 \mathrm{H}, \mathrm{br} \mathrm{s}, \mathrm{OH})$. ESI-MS (positive mode): $\mathrm{m} / \mathrm{z}$ $711.0\left(\mathrm{M}+\mathrm{Na}^{+}\right)$.

\section{Encapsulation of Dil dye: solvent diffusion method}

For DiI dye encapsulation, a solvent diffusion method was used. To $1.0 \mathrm{~mL}$ of nanoceria (PNC or FNC, $1.5 \times 10^{-3} \mathrm{~mol}$ ) suspension, the near infrared DiI dye ( $2 \mu \mathrm{L}$ of $5 \mu \mathrm{M}$ DiI stock in $100 \mu \mathrm{L}$ of DMSO) was added drop-wise with continuous stirring at $1100 \mathrm{rpm}$ at room temperature. The solution was incubated on table-mixer for $3 \mathrm{~h}$ and then the resulting solution was dialyzed against PBS $(\mathrm{pH}=7.4)$ for $2 \mathrm{~h}$ to remove free dye from the solution. The encapsulation efficiency was measured using the following equation, $\mathrm{EE} \%=$ [(Cargo added - Free "unencapsulated cargo")/Cargo added] $\times 100$, and the measurements were performed using UV-Vis spectroscopy. The purified dyeencapsulated FNC $\left(1.0 \times 10^{-3} \mathrm{~mol}\right)$ was stored at $4{ }^{\circ} \mathrm{C}$ for further studies.

\section{Co-encapsulation of lactonic sophorolipids (LSL) and ganetespib (GT)}

Using a modified solvent diffusion method, the drug or combination of drugs and dye were co-encapsulated in FNC. Briefly, a solution of either LSL and DiI dye, or GT and DiI dye, or LSL/GT and DiI dye $(2 \mu \mathrm{M}$ of drug in $100 \mu \mathrm{L}$ DMSO) was added drop-wise to $1.0 \mathrm{~mL}$ of vortexing FNC suspension $\left(1.5 \times 10^{-3} \mathrm{~mol}\right)$, followed by overnight incubation. The drug-encapsulated FNC was dialyzed against PBS $(\mathrm{pH}=7.4)$ for $3 \mathrm{~h}$. The purified suspension $\left(1.0 \times 10^{-3}\right.$ mol) was stored at $4{ }^{\circ} \mathrm{C}$ for further characterizations. Presence of encapsulating cargos were confirmed by using US-Vis and fluorescence spectrophotometry.

Encapsulation efficiency of encapsulating drugs: To measure \%EE of FNC, first concentrated solution was prepared by dissolving lyophilized FNC powder in PBS (pH 7.4). Mini dialysis cup (MWCO 6-8 kDa) was used and a smaller scale dynamic dialysis was performed to collect unencapsulated drug from outside chamber. The FNC solution $\left(50 \mu \mathrm{L}, 10 \times 10^{-3}\right.$ mol) was mixed with acidic PBS solution $(100 \mu \mathrm{L}, \mathrm{pH}$ $=5.0$ ) before taking in the dialysis cup. The UV/Vis absorption of unencapsulated drug was performed (SI Figure S2, Ganetespib $\lambda_{\max }=254$ and $288 \mathrm{~nm}$, LSL $\lambda_{\max }=256 \mathrm{~nm}$ ) and the concentration was calculated using a standard calibration curve. The encapsulation efficiency was measured using the following equation, $\mathrm{EE} \%=[($ Cargo added - Free "unencapsulated cargo")/Cargo added] × 100 .

\section{Cargos release study}

The dye release studies were carried out by using a dynamic dialysis technique at $37^{\circ} \mathrm{C}$. Drug/dye loaded FNC $\left(1.0 \mathrm{~mL}, 1.0 \times 10^{-3} \mathrm{~mol}\right)$ was packed in a dialysis bag and suspended in 2 different environments of PBS $(200 \mu \mathrm{L}, \mathrm{pH} 7.4$ and 6.0). The amount of DiI dye molecules released from FNC into the outer container ( $\mathrm{Di}$ water, $200 \mathrm{~mL}$ ) was determined at regular time intervals by taking $1 \mathrm{~mL}$ aliquots from the outer container. Fluorescence emission was measured at $585 \mathrm{~nm}$ for Dil dye. For the drug release study in the presence of esterase enzyme, $200 \mu \mathrm{L}$ of porcine liver esterase $(1.0 \mathrm{mM})$ were added instead of PBS buffer of pH 6.0. The concentration of dye released was calculated using standard calibration curve and the cumulative release versus time was calculated using the following equation:

$$
\begin{gathered}
\text { Cumulative release }(\%)=(\text { dye released })_{\mathrm{t}} /(\text { dye } \\
\text { released })_{\text {total }} \times 100,
\end{gathered}
$$

where (dye released $)_{t}$ is the amount of dye released at time $t$, and (dye released) total is the total dye present in the dye/drug encapsulated nanoparticles.

\section{In vitro cell studies}

\section{Cell viability assays (MTT assay)}

To determine the time-dependent cytotoxicity, two different cell lines, lung carcinoma (A549 cells) and Chinese hamster ovarian cells (CHO cells) were used. Cells were seeded in 96-well plates at a density of 2,500 cells per well and treated with various functional folate conjugated nanoceria $\left(35 \mu \mathrm{L}, 1.0 \times 10^{-3}\right.$ mol) and incubated at $37^{\circ} \mathrm{C}$ for different time points. Each well was washed twice with PBS and then incubated with $50 \mu \mathrm{L}$ of $5 \mathrm{mM}$ MTT solution. After 4-6 $h$ of incubation, the resulting formazan crystals (purple color) were dissolved in acidic isopropanol $(75 \mu \mathrm{L})$ and the absorbance was recorded at $570 \mathrm{~nm}$ using TECAN's microplate reader. The assay was carried out in triplicates and the results were reported.

\section{Cellular internalization study using fluorescence microscopy}

Lung carcinoma cells (A549 cells) and Chinese Hamster Ovarian cells (CHO - Healthy cells) were seeded into the culture dishes and grown overnight. Once the cells are $75 \%$ confluent $(10,000$ cells/well), 
different functional drug-loaded nanoceria (PNC-DiI, FNC-DiI, FNC-DiI-LSL-GT, $50 \mu \mathrm{L}, 1.0 \times 10^{-3} \mathrm{~mol}$ ) were treated to the cells and incubated at $37^{\circ} \mathrm{C}$ for $24 \mathrm{~h}$. The cells were washed thrice with 1 X PBS ( $\mathrm{pH}=7.4)$ and were fixed with $4 \%$ formaldehyde solution for $15 \mathrm{~min}$ at room temperature. The cells were again washed with 1X PBS before treating with DAPI dye (5 $\mathrm{mg} / \mathrm{mL}$ ) for staining cell nuclei. The cells were then washed with 1X PBS and optical images were taken using fluorescence microscope for cellular internalization of dyes and killing of cells. For control experiment, $\mathrm{CHO}$ cells were treated with FNC-DiI-LSL-GT $\left(50 \mu \mathrm{L}, 1.0 \times 10^{-3} \mathrm{~mol}\right)$ and the images were captured using a fluorescence microscope.

\section{Cytosolic ROS detection assay}

To know the mechanism of cell death, reactive oxygen species (ROS) assay was performed. This assay determines the process of induction of stress to the cells by the generation of ROS. A549 cells were seeded in 12-well plates at a density of 10,000 cells per well and treated with FNC encapsulated with different drugs $\left(50 \mu \mathrm{L}, 1.0 \times 10^{-3} \mathrm{~mol}\right)$ and incubated at $37^{\circ} \mathrm{C}$. After $6 \mathrm{~h}$ of incubation, the cells were washed thrice with $1 X$ PBS ( $\mathrm{pH}=7.4$ ) and stained with $20 \mu \mathrm{L}$ of DHE $(32 \mu \mathrm{M})$ fluorescent probe for about $30 \mathrm{~min}$ at room temperature followed by washing the cells twice with 1X PBS. Subsequently, the cells were fixed with $1 \mathrm{~mL}$ of paraformaldehyde solution. After fixation, the cells were washed with 1X PBS, stored with $2 \mathrm{~mL}$ PBS in each well and images were taken using fluorescence microscope.

\section{Quantification of ROS fluorescent images}

Using ROS fluorescent images, the amount of ROS generated (equivalent to red fluorescence) was quantified using commercial ImageJ software. Particular cell from each treated well was selected to get a stack of values for the area, integrated density, and mean fluorescence of background readings. The corrected total cell fluorescence (CTCF) for each well was calculated using the formula: CTCF $=$ integrated density - (area of selected cell X mean fluorescence of background readings).

\section{Apoptosis and necrosis detection assay}

For the assessment of apoptosis and necrosis, Annexin V-FITC and Ethidium homodimer III kit was used. Briefly, A549 cells were seeded in 12-well plates at a density of 10,000 cells per well. Next, cells were treated with different preparations (FNC, FNC-LSL, FNC-GT and FNC-LSL-GT, $\left.50 \mu \mathrm{L}, 1.0 \times 10^{-3} \mathrm{~mol}\right)$. After $6 \mathrm{~h}$ of incubation, the cells were washed twice with $1 \mathrm{X}$ PBS $(\mathrm{pH}=7.4)$ and stained with two different dyes, 5 $\mu \mathrm{L}$ of FITC-annexin buffer and $5 \mu \mathrm{L}$ of ethidium homodimer III and incubated for $15 \mathrm{~min}$ in the dark.
Later the cells were washed twice with 1X binding buffer and fixed with $4 \%$ formaldehyde solution and the cells were covered with $1 \mathrm{X}$ binding buffer. Multiple fluorescence images were taken using two filters: green fluorescence representing apoptosis, red fluorescence indicating necrosis.

\section{Migration assay}

Experimental procedure involves the incubation of serum starved A549 cells for $24 \mathrm{~h}$. Next, the cells were harvested and treated with FNC and drugs-loaded FNC $\left(50 \mu \mathrm{L}, 1.0 \times 10^{-3} \mathrm{~mol}\right)$. Subsequently, the cells were seeded in invasion chamber of the migratory assay kit coated with collagen layer. The feeder tray contained 10\% FBS media and the complete set up was incubated at $37^{\circ} \mathrm{C}$ for $24 \mathrm{~h}$ to allow the migration of cells. Later, the migratory cells were dislodged completely from the invasion chamber and placed on new feeder tray containing cell detachment buffer and incubated for $30 \mathrm{~min}$. Finally, diluted solution of CyQuant GR dye and cell lysis buffer was added to stain migratory cells and the fluorescence intensity was measured at an emission wavelength of $520 \mathrm{~nm}$, using a microplate reader.

\section{HDAC inhibition assay}

HDAC fluorometric assay kit was used to determine the HDAC inhibition ability of lactonic sophorolipids (LSL). Assay was performed according to manufacturer's protocol. HeLa nuclear extract and Trichostatin A were used as positive and negative controls respectively. Briefly, A549 cells were seeded in a 96 -well microtiter plates and after $80 \%$ confluence $(2,500$ cells/well), the cells were treated with functional nanoceria $\left(50 \mu \mathrm{L}, 1.0 \times 10^{-3} \mathrm{~mol}\right)$ and incubated at $37{ }^{\circ} \mathrm{C}$ for $24 \mathrm{~h}$. Positive and negative controls were added along with HDAC assay buffer and the reaction was initiated by adding HDAC fluorometric substrate, and incubated for $30 \mathrm{~min}$. Later, the HDAC lysine developer was added to stop the reaction and was incubated for additional $15 \mathrm{~min}$. The fluorescence intensity was then measured at 460 $\mathrm{nm}$ using a microplate reader.

\section{Conclusions}

In summary, we successfully demonstrated the potential anticancer property of LSL using folate functionalized nanoceria (FNC) for the targeted treatment of K-RAS driven NSCLC. Characterization studies on FNC showed its enhanced stability in PBS at physiological conditions. The functionalization of surface carboxylic acids with folate allowed targeting and, consequently, enhanced uptake by the non-small cell lung cancer (NSCLC) cell line A549, an epithelial 
carcinoma that is a KRAS mutant. Formulated nanoceria showed higher encapsulation efficiency of drugs. Results in this work demonstrate that by combining LSL with GT inside the FNC nanocarrier, these drugs synergistically enhanced hsp90 inhibition, as confirmed by several cell-based assays. Fluorescence microscopy images confirmed the successful receptor-mediated cellular targeting and cell internalization of A549 cells using folate functionalized NC. FNC-LSL-GT caused an $80 \%$ decrease in A549 cell viability during a $24 \mathrm{~h}$ incubation. Furthermore, the mechanisms of action of FNC-LSL-GT involved Hsp90 and HDAC inhibitions that resulted in the enhanced intracellular ROS that facilitated the apoptotic pathway. Furthermore, FNC-LSL-GT demonstrated metastasis suppressing activity based on a mobility assay. We conclude, based on the in vitro assays conducted herein to assess the anti-cancer activities of LSL and FNC-LSL-GT on the A549 cell line, that the reported results are encouraging and warrant further investigation of the potential of this therapeutic system for the treatment of NSCLC and related cancer diseases.

\section{Supplementary Material}

Supplementary figures.

http://www.ntno.org/v05p0391s1.pdf

\section{Acknowledgements}

\section{Authors' information}

T.B., S.N. and S.S. thank the Kansas INBRE Bridging grant (K-INBRE P20GM103418) for funding of this work. F.T. and R.G. thank the NSF Division of Materials Research (NSF-DMR) Biomaterials (BMAT) grant 1508422 for funding this work. We thank Truptiben Patel and Raghunath Narayanam for the help with editing this manuscript.

\section{Competing Interests}

The authors have declared that no competing interest exists.

\section{References}

1. He S, Smith DL, Sequeira M, Sang J, Bates RC, Proia DA. The HSP90 inhibitor ganetespib has chemosensitizer and radiosensitizer activity in colorectal cancer. Invest. New Drugs. 2014; 32: 577-586.

2. Ropero S, Esteller M. The role of histone deacetylases (HDACs) in human cancer. Mol Oncol. 2007; 1: 19-25.

3. Peserico A, Simone C. Physical and Functional HAT/HDAC Interplay Regulates Protein Acetylation Balance. J Biomed Biotechnol. 2011; 2011: 371832.

4. Chen HP, Zhao YT, Zhao TC. Histone deacetylases and mechanisms of regulation of gene expression. Crit Rev Oncog. 2015; 20: 35-47.

5. De Ruijter AJM, Van Gennip AH, Caron HN, Kemp S, Van Kuilenburg ABP. Histone deacetylases (HDACs): characterization of the classical HDAC family. Biochem J. 2003. 370: 737-749.

6. Bali P, Pranpat M, Bradner J, Balasis M, Fiskus W, Guo F, Rocha K, Kumaraswamy S, Boyapalle S, Atadja P, Seto E, Bhalla K. Inhibition of Histone Deacetylase 6 Acetylates and Disrupts the Chaperone Function of Heat Shock
Protein 90: a novel basis for antileukemia activity of histone deacetylase inhibitors. J Biol Chem. 2005; 280: 26729-26734

7. Kurtzman CP, Price NPJ, Ray KJ, Kuo TM. Production of sophorolipid biosurfactants by multiple species of the Starmerella (Candida) bombicola yeastclade. FEMS Microbiol Lett. 2010; 311: 140-146.

8. De Oliveira MR, Camilios-Neto D, Baldo C, Magri A, Celligoi MAPC. Biosynthesis and Production of Sophorolipids. Int J Sci Tech Res. 2014; 3: 133-146.

9. Hardin R, Pierre J, Schulze R, Mueller CM, Fu SL, Wallner SR, Stanek A, Shah V, Gross RA, Weedon J, Nowakowski M, Zenilman ME, Bluth MH. Sophorolipids Improve Sepsis Survival: Effects of Dosing and Derivatives. J Surg Res. 2007; 142: 314-319.

10. Sleiman JN, Kohlhoff SA, Roblin PM, Wallner S, Gross R, Hammerschlag MR, Zenilman ME, Bluth MH. Sophorolipids as Antibacterial Agents. Ann Clin Lab Sci. 2009; 39: 60-63

11. De Oliveira MR, Magri A, Baldo C, Camilios-Neto D, Minucelli T, Celligoi MAPC. Review: Sophorolipids A Promising Biosurfactant and it's Applications. Intl J Adv Biotec and Res. 2015; 6: 161-174.

12. Xu WS, Parmigiani RB, Marks PA. Histone deacetylase inhibitors: molecular mechanisms of action. Oncogene 2007; 26: 5541-5552.

13. New M, Olzscha H, La Thangue NB. HDAC inhibitor-based therapies: can we interpret the code? Mol Oncol. 2012; 6: 637-656.

14. Callaghan B, Lydon H, Roelants SLKW, Van Bogaert INA, Marchant R, Banat IM, Mitchell CA. Lactonic Sophorolipids Increase Tumor Burden in Apcint/Mice. PLoS One. 2016; 11: e0156845.

15. Rashad MM, Nooman MU, Ali MM, Al-kashef AS, Mahmoud AE. Production, characterization and anticancer activity of Candida bombicola sophorolipids by means of solidstate fermentation of sunflower oil cake and soybean oil. Grasas Aceites 2014; 65: e017.

16. Marks PA. The clinical development of histone deacetylase inhibitors as targeted anticancer drugs. Expert Opin Investig Drugs 2010; 19: 1049-1066.

17. Molina JR, Yang P, Cassivi SD, Schild SE, Adjei AA. Non-small cell lung cancer: epidemiology, risk factors, treatment, and survivorship. Mayo Clin Proc. 2008; 83: 584-594.

18. Sukumar UK, Bhushan B, Dubey P, Matai I, Sachdev A, Pakirisamy G. Emerging applications of nanoparticles for lung cancer diagnosis and therapy. Int Nano Lett. 2013; 3: 45

19. Sadhukha T, Wiedmann TS, Panyam J. Inhalable magnetic nanoparticles for targeted hyperthermia in lung cancer therapy. Biomaterials 2013; 34: 51635171.

20. Oser MG, Niederst MJ, Sequist LV, Engelman JA. Transformation from non-small-cell lung cancer to small-cell lung cancer: molecular drivers and cells of origin. Lancet Oncol. 2015; 16: 165-172.

21. Ahmad J, Akhter S, Rizwanullah Md, Amin S, Rahman M, Ahmad MZ, Moshahid Alam Rizvi Kamal MA, Ahmad FJ. Nanotechnology-based inhalation treatments for lung cancer: state of the art. Nanotechnol Sci and Appl. 2015; 8: 55-66.

22. Munaweera I, Shi Y, Koneru B, Saez R, Aliev A, Di Pasqua AJ, Balkus KJ. Jr. Chemoradiotherapeutic Magnetic Nanoparticles for Targeted Treatment of Nonsmall Cell Lung Cancer. Mol Pharma. 2015; 12: 3588-3596.

23. Ramalingam SS, Owonikoko TK, Khuri FR. Lung cancer: new biological insights and recent therapeutic advances. CA Cancer J Clin. 2011; 61: 91-112.

24. Jemal A, Bray F, Center MM, Ferlay J, Ward E, Forman D. Global cancer statistics. CA Cancer J Clin. 2011; 61: 69-90.

25. Shen S, Mao CQ, Yang XZ, Du XJ, Liu Y, Zhu YH, Wang J. Cationic lipid-assisted polymeric nanoparticle mediated GATA2 siRNA delivery for synthetic lethal therapy of KRAS mutant non-small-cell lung carcinoma. Mol. Pharma. 2014; 11: 2612-2622.

26. Westcott PMK, To MD. The genetics and biology of K-RAS in lung cancer. Chin J Cancer 2013; 32: 63-70.

27. D'Arcangelo M, Cappuzzo FK-Ras Mutations in Non-Small-Cell Lung Cancer: Prognostic and Predictive Value. ISRN Mol Biol. 2012; 2012: 8 .

28. Ramalingam S, Belani C. Systemic chemotherapy for advanced non-small cell lung cancer: recent advances and future directions. Oncologist 2008; 13: 5-13.

29. Grossi F, Kubota K, Cappuzzo F, Marinis F.de., Gridelli C, Aita M, Douillard JY. Future Scenarios for the Treatment of Non-Small Cell Lung Cancer: Focus on Taxane-Containing Regimens. Oncologist 2010; 15: 1102-1112.

30. Kallu J, Banerjee T, Sulthana S, Darji S, Higginbotham R, Fletcher C, Gerasimchuk NN, Santra S. Nanomedicine-Assisted Combination Therapy of NSCLC: New Platinum-Based Anticancer Drug Synergizes the Therapeutic Efficacy of Ganetespib. Nanotheranostics 2019; 3: 120-134.

31. Sulthana $S$, Banerjee $T$, Kallu J, Vuppala SR, Heckert B, Naz S, Shelby T, Yambem O, Santra S. Combination Therapy of NSCLC Using Hsp90 Inhibitor and Doxorubicin Carrying Functional Nanoceria. Mol Pharma. 2017; 14: 875-884.

32. Jhaveri K, Modi S. Ganetespib: research and clinical development. Oncotargets and Ther. 2015; 8: 1849-1858.

33. Tsutsumi S, Beebe K, Neckers L. Impact of heat-shock protein 90 on cancer metastasis. Future Oncol. 2009; 5: 679-688.

34. Li Y, Zhanga T, Sun D. New developments in Hsp90 inhibitors as anti-cancer therapeutics: mechanisms, clinical perspective and more potential. Drug Resist Updat. 2009; 12: 17-27.

35. Shimamura T, Shapiro GI. Heat Shock Protein 90 Inhibition in Lung Cancer. J Thorac Oncol. 2008; 3: S152-S159. 
36. Beck R, Dejeans N, Glorieux C, Pedrosa RC, Vásquez D, Valderrama JA, Calderon PB, Verrax J. Molecular Chaperone Hsp90 as a Target for Oxidant-Based Anticancer Therapies. Curr Med Chem. 2011; 18: 1-10.

37. Rios D, Benites J, Valderrama JA, Farias M, Pedrosa RC, Verrax J, Buc Calderon P. Biological evaluation of 3-acyl-2-acrylamino-1, 4-napthaquinones as inhibitors of Hsp90 chaperoning function. Curr Top Med Chem. 2012; 12: 2094-2102.

38. Tassa C, Shaw SY, Weissleder R. Dextran-coated iron oxide nanoparticles: a versatile platform for targeted molecular imaging, molecular diagnostics and therapy. Acc Chem Res. 2011; 44: 842-852.

39. Santra S, Jativa SD, Kaittanis C, Normand G, Grimm J, Perez JM. Gadolinium-Encapsulating Iron Oxide Nanoprobe as Activatable NMR/MRI Contrast Agent. ACS Nano. 2012; 6: 7281-7294.

40. Lin W, Huang YW, Zhou XD, Ma Y. Toxicity of cerium oxide nanoparticles in human lung cancer cells. Int J Toxicol. 2006; 25: 451-457.

41. Jin Y, Kanan S, Wu M, Zhao JX. Toxicity of luminescent silica nanoparticles to living cells. Chem Res Toxicol. 2007; 20: 1126-1133.

42. Mann A, Gerasimchuk N, Silchenko S. New non-aggregating bivalent cis-ML2 $(\mathrm{M}=\mathrm{Pd}, \mathrm{Pt} ; \mathrm{L}=$ pivaloylcyanoxime). Inorganica Chimica Acta. 2016; 440: 118-128.

43. Qian Y, Qiu M, Wu Q, Tian Y, Zhang Y, Gu N, Li S, Xu L, Yin R. Enhanced cytotoxic activity of cetuximab in EGFR-positive lung cancer by conjugating with gold nanoparticles. Sci Rep. 2014; 4: 1-8.

44. Can $\mathrm{Xu}$, Xiaogang $\mathrm{Qu}$. Cerium oxide nanoparticle: a remarkably versatile rare earth nanomaterial for biological applications. NPG Asia Materials. 2014; 6: e90.

45. Pulido-Reyes G, Rodea-Palomares I, Das S, Sakthivel TS, Leganes F, Rosal R, Seal S, Fernández-Piñas F. Untangling the biological effects of cerium oxide nanoparticles: the role of surface valence states. Sci Rep. 2015; 5: 15613.

46. Nelson BC, Johnson ME, Walker ML, Riley KR, Sims CM. Antioxidant Cerium Oxide Nanoparticles in Biology and Medicine. Antioxidants (Basel). 2016; 5: 15.

47. Giri S, Karakoti A, Graham RP, Maguire JL, Reilly CM, Seal S, Rattan R, Shridhar V. Nanoceria: A Rare-Earth Nanoparticle as a Novel Anti Angiogenic Therapeutic Agent in Ovarian Cancer. PLoS One. 2013; 8: e54578.

48. Dowding JM, Das S, Kumar A, Dosani T, McCormack R, Gupta A, Sayle TXT, Sayle DC, Kalm LV, Seal S, Self WT. Cellular Interaction and Toxicity Depend on Physicochemical Properties and Surface Modification of Redox-Active Nanomaterials. ACS Nano. 2013; 7: 4855-4868.

49. Sack M, Alili L, Karaman E, Das S, Gupta A, Seal S, Brenneisen P. Combination of conventional chemotherapeutics with redox-active cerium oxide nanoparticles - a novel aspect in cancer therapy. Mol Cancer Ther. 2014; 13: 1740-1749.

50. Asati A, Santra S, Kaittanis C, Nath S, Perez JM. Oxidase-like activity of polymer-coated cerium oxide nanoparticles. Angew Chem Int Ed Engl. 2009; 48: 2308-2312

51. Perez JM, Asati A, Nath S, Kaittanis C. Synthesis of biocompatible dextran-coated nanoceria with $\mathrm{pH}$-dependent antioxidant properties. Small. 2008; 4: 552-556.

52. Nguyen A, Su L, Campbell B, Poulin NM, Nielsen TO. Synergism of heat shock protein 90 and histone deacetylase inhibitors in synovial sarcoma. Sarcoma. 2009; 2009: 794901.

53. Kramer OH, Mahboobi S, Sellmer A. Drugging the HDAC-HSP90 interplay in malignant cells. Trends in Pharmacol Sci. 2014; 35: 501-509.

54. Asati A, Santra S, Kaittanis C, Perez JM. Surface-charge-dependent cell localization and cytotoxicity of cerium oxide nanoparticles. ACS Nano. 2010; 4: 5321-5331.

55. Santra S, Kaittanis C, Grimm J, Perez JM. Drug/dye-loaded, multifunctional iron oxide nanoparticles for combined targeted cancer therapy and dual optical/magnetic resonance-Imaging. Small. 2009; 5: 1862.

56. Felse PA, Shah V, Chan J, Rao KJ, Gross RA. Sophorolipid biosynthesis by Candida bombicola from industrial fatty acid residues. Enzyme and Microbial Technology. 2007; 40: 316-323.

57. Bisht KS, Gao W, Gross RA. Glycolipids from Candida bombicola: Polymerization of 6-O-Acryl Sophorolipid Derivative. Macromolecules. 2000; 33: 6208-6210. 